DOI: https://doi.org/10.24127/ajpm.v9i3.2995

\title{
PENGEMBANGAN BAHAN AJAR MATEMATIKA EKONOMI BERBASIS V-LOG BERORIENTASI PADA KEMAMPUAN PENGUASAAN KONSEP DAN KOMUNIKASI MATEMATIS
}

\author{
Isnaini Mahuda ${ }^{1}$, Amah Suhamah $^{2}$, Anton Nasrullah ${ }^{3 *}$, Beni Junedi ${ }^{4}$ \\ ${ }^{1,2}$ Matematika, Universitas Bina Bangsa, Serang, Indonesia \\ ${ }^{3 *}, 4$ Pendidikan Matematika, Universitas Bina Bangsa, Serang, Indonesia \\ *Corresponding author. JL Raya Serang - Jakarta, KM. 03 No. 1B, Banten 42124, Serang, Indonesia \\ E-mail: $\quad$ isnaini.mahuda@binabangsa.ac.id ${ }^{1)}$ \\ amah.suhamah@binabangsa.ac.id ${ }^{2}$ \\ anton.nasrullah@binabangsa.ac.id ${ }^{3 *)}$ \\ beni.junedi@binabangsa.ac.id $^{4)}$
}

Received 28 July 2020; Received in revised form 09 September 2020; Accepted 17 September 2020

\begin{abstract}
Abstrak
Penelitian ini bertujuan untuk: a) mendeskripsikan desain bahan ajar Matematika Ekonomi berbasis vlog; b) mengukur tingkat kevalidan bahan ajar Matematika Ekonomi berbasis vlog menurut para ahli; c) mengukur tingkat kepraktisan bahan ajar Matematika Ekonomi berbasis vlog menurut mahasiswa pengguna; dan d) mengetahui tingkat efektivitas bahan ajar Matematika Ekonomi berbasis vlog terhadap kemampuan penguasaaan konsep dan komunikasi matematis mahasiswa pengguna. Metode penelitian ini menggunakan mixed-method dengan pendekatan penelitian dan pengembangan. Bahan ajar Matematika Ekonomi berbasis vlog dikembangkan dengan model pngembangan 4D (Define, Design, Develop dan Disseminate). Subjek dari penelitian ini adalah mahasiswa semester II jurusan Manajemen Fakultas Ekonomi dan Bisnis Universitas Bina Bangsa yang sedang mengambil mata kuliah Matematika Ekonomi. Hasil uji kevalidan dari para ahli yang terdiri dari ahli materi, ahli media dan ahli bahasa diperoleh bahwa bahan ajar Matematika Ekonomi berbasis vlog termasuk pada kriteria kelayakan sangat valid. Uji kepraktisan oleh mahasiswa pengguna bahan ajar diperoleh bahwa bahan ajar Matematika Ekonomi berbasis vlog termasuk dalam kriteria sangat praktis. Adapun uji efektivitas bahan ajar Matematika Ekonomi berbasis vlog efektif dalam meningkatkan kemampuan penguasaan konsep dan komunikasi matematis mahasiswa.
\end{abstract}

Kata kunci: Bahan ajar; kemampuan komunikasi matematis; kemampuan penguasaan konsep; vlog.

\begin{abstract}
The purpose of this study is to: a) describe the design of vlog-based Mathematics Economics teaching materials; b) measure the validity of vlog-based Mathematics Economics teaching materials according to experts; c) measure the practicality of vlog-based Mathematics Economics teaching materials according to student users; and d) measure the effectiveness of vlog-based Mathematics Economic teaching materials on the ability to mastery of mathematical concepts and mathematical communication of user students. This research method uses mixed-method with a research and development approach. Vlogbased Mathematics Economic teaching materials are developed using the 4D development model (Define, Ddesign, Develop and Disseminate). The subjects of this study is the 2nd semester students majoring in Management, Faculty of Economics and Business, University of Bina Bangsa who were currently taking Mathematics Economics courses. Validation test results from experts consisting of material experts, media experts and linguists obtained that the vlog-based Mathematics Economics teaching materials are very valid. Practicality test by students who use teaching materials is obtained that the vlog-based Mathematics Economics teaching material is very practical criteria. The effectiveness test of Vlog-based Mathematics Economics teaching materials is effective in improving students' mathematical concepts and mastery ability.
\end{abstract}

Keywords: Concept mastery ability; mathematical communication ability; teaching materials; vlog. 
DOI: https://doi.org/10.24127/ajpm.v9i3.2995

\section{PENDAHULUAN}

Pemanfaatan teknologi digital tidak bisa terlepas di dalam aktivitas belajar saat ini. Dalam perjalanan menghadapi tantangan digitalisasi ternyata dunia pendidikan juga mau tidak mau harus siap dengan transformasi yang terjadi akibat adanya pandemi Covid-19 yang menjadi masalah global di tahun 2020. Adanya penerapan social distancing dalam meminimalisir penyebaran Covid-19 mengharuskan sistem pembelajaran dilakukan secara daring. Peserta didik mulai dari tingkat dasar hingga perguruan tinggi diwajibkan belajar dari rumah untuk mencegah terjadinya penularan Covid-19. Pada kondisi darurat ini tentu saja memaksa para guru/dosen, siswa/mahasiswa juga para orangtua untuk bisa memanfaat perangkat pembelajaran yang dapat mendukung terlaksananya pembelajaran secara daring.

Dalam pembelajaran daring pendidik dituntut mampu mengemas bahan ajar yang lebih kreatif agar tujuan pembelajaran tetap tercapai sekalipun pembelajaran tidak dilakukan secara tatap muka. Fakta yang terjadi dalam pembelajaran daring pada mata kuliah Matematika Ekonomi, dosen memberikan bahan ajar berupa Modul (PDF dan Power-point) kepada mahasiswa menggunakan media WhatsApp Grup, Google Classroom, Edmodo dan aplikasi lainya. Bahan ajar dalam bentuk modul tersebut belum mampu dipahami dengan baik oleh mahasiswa karena dalam memahami sebuah konsep matematika diperlukan penjelasan yang lebih rinci dari dosen secara lisan. Beberapa respon dari mahasiswa menyampaikan bahwa bahan ajar yang diberikan belum mampu menjelaskan materi secara rinci, diperlukan penjelasan materi dalam bentuk video yang dapat dilihat dan di dengar secara langsung. Pembelajaran menggunakan video memberikan manfaat materi dapat diputar ulang kembali oleh mahasiswa apabila materi kurang bisa dipahami. Salah satu bentuk pembelajaran menggunakan video yaitu pembelajaran berbasis vlog.

Blog video (bahasa Inggris: videoBlogging, atau bisa disingkat "vlog" atau vlogging (diucapkan "vlogging", bukan "v-logging"), atau vidblogging, merupakan suatu bentuk kegiatan blogging dengan menggunakan medium video. Vlog adalah satu video berisi mengenai opini, cerita atau kegiatan harian yang biasanya dibuat tertulis pada blog atau youtube (David, 2017); (Lestari, 2019); (Karamina, 2020). Aktivitas vlog (vlogging) adalah satu kegiatan penyampaian pesan dengan media utamanya yaitu video diatas teks dan audio sebagai sumber utama. Kebanyakan vlog digunakan sebagai media hiburan namun saat ini vlog juga sudah mulai digunakan sebagai media edukatif yang dapat digunakan oleh para pendidik untuk menyampaikan materi pembelajaran (Susanti, 2020).

Vlog merupakan hasil dari perkembangan teknologi informasi dan komunikasi berbasis internet yang dapat dimanfaatkan sebagai media pembelajaran untuk meningkatkan minat belajar melalui penugasan dan kreatifitas dalam penyampaian materi maupun dalam mempresentasikan hasil karya tugas (Priana, 2017). Selain itu, hasil penelitian mengatakan bahwa vlog sebagai media pembelajaran dapat memberikan dampak signifikan kepada kegiatan belajar mengajar dan layak untuk dijadikan sebagai media pembelajaran (Al Hibra, 2019).

Desain bahan ajar berbasis vlog dapat diterapkan dalam perkuliahan Matematika Ekonomi. Bahan ajar berbasis vlog ini dapat diakses secara 
daring menggunakan channel Youtube. Dengan demikian, perkuliahan Matematika Ekonomi sekalipun dilakukan secara daring dapat meningkatkan penguasaan konsep mahasiswa. Beberapa hasil penelitian menyatakan bahwa pembelajaran dengan media vlog dapat meningkatkan penguasaan konsep (Fitriyani L. D., 2017); (Wachid Muzhaffar, 2020). Bahan ajar berbasis vlog dapat memberikan nuansa baru, tantangan baru dan memberikan pengalaman belajar yang lebih menyenangkan bagi mahasiswa, video dapat ditonton kapan saja dan dimana saja bahkan dapat diputar berulang-ulang sehingga mahasiswa dapat lebih mudah memahami materi dan menguasai konsep matematika yang diajarkan. Selain itu, mahasiswa juga dapat mengoptimalkan penggunaan gadget yang mereka miliki untuk kegiatan belajar yang lebih bermanfaat ketimbang mengakses jejaring sosial, mengakses game online ataupun mengakses situs-situs hiburan yang tidak terlalu penting.

Penguasaan konsep matematika adalah suatu kesanggupan dan kemampuan seseorang untuk menuangkan ide yang dimiliki dalam bentuk abstak ke hal yang konkret sehingga dapat dengan mudah dipahami oleh orang lain dalam pembelajaran matematika (Irawan, 2014); (Akuba, 2020).

Aspek kemampuan matematika lain yang menjadi orientasi dalam penyusunan bahan ajar berbasis vlog ini adalah kemampuan komunikasi matematis. Kemampuan komunikasi matematis menjadi hal yang sangat penting sekalipun di dalam proses pembelajaran daring. Hal ini dikarenakan pada beberapa kasus mahasiswa mampu menguasai konsep matematis namun tidak jarang dari mereka yang merasa kesulitan untuk mengomunikasikan yang dipahaminya kepada orang lain pada masa pembelajaran didalam kelas sebelum pandemic. Apalagi pada masa pandemik mahasiswa harus belajar secara daring dan mampu mengkomunikasikan yang mereka pahami kepada orang lain. Keterampilan kemampuan komunikasi dalam menjelaskan pemecahan masalah yang mahasiswa pahami kepada orang lain dalam rangka untuk menghadapi kebutuhan revolusi industry 4.0. Hal ini menjadi dasar penelitian pelaksanaan pembelajaran ditengah masa pandemic dan berfokus pada peningkatan kemampuan komunikasi mahasiswa.

Dari hasil observasi 25 mahasiswa di kelas menunjukan bahwa kemampuan awal komunikasi matematis mahasiswa yang memiliki kriteria tinggi berjumlah 1 orang, kriteria sedang 10 orang dan dalam kriteria rendah 14 orang. Berdasarkan data tersebut menunjukkan bahwa kemampuan komunikasi matematis mahasiswa masih rendah. Dengan demikian, kemampuan komunikasi matematis mahasiswa perlu ditingkatkan.

Komunikasi matematis adalah suatu proses penyampaian gagasan matematika baik secara lisan ataupun tulisan. Komunikasi lisan seperti diskusi dan menjelaskan sedangkan komunikasi tulisan misalnya mengungkapkan ide matematika melalui gambar/grafik, tabel, persamaan dengan bahasa sendiri (Hodiyanto., 2017); (Putri, 2020). Komunikasi matematis menekankan proses interaksi sosial yang melibatkan proses pertukaran gagasan matematis dan merefleksikan informasi, ide, dan pemahaman matematis dengan peserta didik lainnya (Arfah., 2018). Melalui komunikasi matematis peserta didik 
DOI: https://doi.org/10.24127/ajpm.v9i3.2995

dapat saling bertukar pikiran sekaligus mengklarifikasi pemahaman dan pengetahuan mengenai konsep matematika yang mereka dapatkan selama proses pembelajaran berlangsung. Hasil penelitian yang dilakukan oleh Mugara menyatakan bahwa pembelajaran dengan menerapkan bahan ajar berbasis vlog dapat meningkatkan keterampilan komunikasi mahasiswa (Mugara, 2019).

Berdasarkan pemaparan di atas maka penulis tertarik untuk membuat sebuah desain bahan ajar Matematika Ekonomi berbasis vlog yang beorientasi pada penguasaan konsep dan kemampuan komunikasi matematis di dalam pembelajaran daring menghadapi situasi pandemi Covid-19. Adapun tujuan dari penelitian ini adalah untuk: a) mendeskripsikan desain bahan ajar Matematika Ekonomi berbasis vlog; b) mengukur tingkat kevalidan bahan ajar Matematika Ekonomi berbasis vlog menurut para ahli; c) mengukur tingkat kepraktisan bahan ajar Matematika Ekonomi berbasis vlog menurut mahasiswa pengguna; dan d) mengetahui tingkat efektivitas bahan ajar Matematika Ekonomi berbasis vlog terhadap kemampuan penguasaaan konsep dan komunikasi matematis mahasiswa pengguna.

\section{METODE PENELITIAN}

Penelitian ini bertujuan untuk mendeskripsikan desain bahan ajar Matematika Ekonomi berbasis vlog serta mengukur tingkat kevalidan, kepraktisan, dan efektivitas bahan ajar tersebut. Penelitian dilakukan dengan menggunakan pendekatan penelitian dan pengembangan (research and development) yang dititikberatkan pada desain bahan ajar. Penelitian dan pengembangan merupakan suatu proses atau langkah-langkah untuk mengembangkan atau menghasilkan produk baru yang selanjutnya dilakukan pengujian kualitas dan atau efektifitas dari produk yang dihasilkan. Adapun dalam desain penelitian dan pengembangan ini peneliti memilih model pengembangan 4D. Model ini terdiri dari empat tahap, yaitu: define, design, and develop dan disseminate. Pada penelitian ini tahapan model pengembangan yang dilakukan terbatas pada tahap develop.

Pada tahapan define kegiatan yang dilakukan meliputi analisis awal-akhir, analisis mahasiswa, analisis materi ajar, analisis tugas dan analisis spesifikasi tujuan pembelajaran. Analisis awalakhir dilakukan untuk mengetahui permasalahan yang dihadapi mahasiswa dalam pembelajaran Matematika Ekonomi. Analisis mahasiswa dilakukan untuk mengetahui kondisi secara umum mahasiswa yang selanjutnya akan dijadikan dasar dalam mendesain bahan ajar dengan media yang akan digunakan. Analisis materi ajar berguna untuk menentukan materi yang akan dipelajari dalam pembelajaran. Analisis tugas mengacu pada kompetensi dasar yang ingin dicapai sedangkan analisis spesifikasi tujuan pembelajaran menjabarkan indikator yang lebih spesifik berdasarkan analisis materi dan tugas yang telah dilakukan.

Pada tahap design, dihasilkan suatu produk awal (prototype) atau rancangan produk yang disesuaikan dengan analisis yang telah dilakukan pada tahapan define. Adapun kegiatan yang dilakukan pada tahap ini yaitu pemilihan media, pemilihan format dan produk awal. Pemilihan media disesuaikan dengan karakter mahasiswa, tujuan yang ingin dicapai, serta kemampuan dosen dalam menggunakan media. Pada tahap pemilihan format, 
peneliti merancang isi dan sumber belajar yang akan digunakan sedangkan produk awal dalam hal ini prototype berupa rancangan bahan ajar mahasiswa untuk mata kuliah Matematika Ekonomi pada materi Matriks dan Aplikasinya dalam Ekonomi dan Bisnis.

Pada tahap develop kegiatan yang dilakukan dibagi kedalam dua kegiatan yaitu: expert appraisal dan developmental testing. Pada kegiatan expert appraisal rancangan produk yang sudah dibuat divalidasi oleh para ahli yang terdiri dari ahli media, ahli materi dan ahli bahasa. Kegiatan ini dilakukan untuk melihat kelayakan rancangan produk. Hasil dari kegiatan ini berupa saran atau komentar yang nantinya digunakan untuk memperbaiki rancangan produk yang telah disusun. Sedangkan pada tahap developmental testing, rancangan produk diujicobakan kepada sasaran subjek penelitian, hal ini dilakukan untuk melihat respon, reaksi dan komentar dari sasaran pengguna produk.

Subjek dari penelitian ini adalah mahasiswa semester II jurusan Manajemen Fakultas Ekonomi dan Bisnis Universitas Bina Bangsa yang berjumlah 25 orang. Rancangan produk diujicobakan kepada subjek penelitian untuk mengukur ketercapaian tujuan. Pengukuran ini dilakukan untuk mengetahui tingkat kepraktisan dan efektivitas produk bahan ajar yang dikembangkan.

Implikasi dari penggunaan pendekatan penelitian dan pengembangan (research and development) yaitu data yang dikumpulkan dan dianalisis terdiri dari data kualitatif dan kuantitatif. Dengan demikian metode yang digunakan dalam penelitian ini adalah mixed-method yang merupakan pendekatan penelitian dengan mengkombinaskan antara penelitian kualitatif dan kuantitatif (Creswell, 2013).

Data kualitatif dalam penelitian ini diperoleh dari komentar, kritik dan saran ataupun masukan dari para validator ahli dan respon mahasiswa pengguna. Data ini kemudian dianalisis secara deskriptif kualitatif. Sedangkan data kuantitatif diperoleh dari lembar validasi ahli materi, unutk mengukur kevalidan bahan ajar, angket tanggapan mahasiswa untuk mengukur kepraktisan bahan ajar dan instrument tes yaitu pretes-postes untuk mengukur keefektifan bahan ajar. Soal pretes dan postes disusun berdasarkan indikator kemampuan penguasaan konsep dan komunikasi matematis.

Lembar validasi dan angket respon mahasiswa berisi beberapa item dengan kriteria sangat baik, baik, cukup baik, kurang baik dan sangat kurang baik. Adapun skor skala penilaian angket yang digunakan adalah yang ditampilkan pada Tabel 1.

Tabel 1. Skor Skala Penilaian Angket.

\begin{tabular}{lc}
\hline Pernyataan & Skor \\
\hline Sangat Baik & 5 \\
Baik & 4 \\
Cukup Baik & 3 \\
Kurang & 2 \\
Sangat Kurang & 1 \\
\hline
\end{tabular}

Data yang telah diperoleh dari hasil skor angket selanjutnya dianalisis dengan frekuensi jawaban tiap alternatif yang dipilih responden dikalikan 100\%, seperti pada Rumus (1).

$$
P=\frac{\sum x}{\sum x_{i}} \cdot 100 \%
$$


DOI: https://doi.org/10.24127/ajpm.v9i3.2995

Keterangan:

$P=$ Presentase Kelayakan

$\sum x=$ Jumlah total jawaban skor

$\sum x_{i}=$ Jumlah total jawaban tertinggi

Konversi hasil persentase kelayakan kedalam kategori atau kriteria kelayakan dilakukan berdasarkan tabel kualifikasi penilaian berikut (Arikunto, 2010):

Tabel 2. Tingkat Penilaian dan Kualifikasi Penilaian.

\begin{tabular}{cccc}
\hline Persentase & \multicolumn{2}{c}{ Kriteria Kelayakan } & \\
\cline { 2 - 3 } Kelayakan & Uji & Uji & Ket. \\
\cline { 2 - 3 } & Kevalidan & Kepraktisan & \\
\hline$P \leq 20$ & Tidak & Tidak & Revisi \\
& Valid & Praktis & \\
$20<P \leq$ & Kurang & Kurang & Revisi \\
40 & Valid & Praktis & \\
$40<P \leq$ & Cukup & Cukup & Revisi \\
60 & Valid & Praktis & Kecil \\
$60<P \leq$ & Valid & Praktis & Tidak \\
80 & & & Perlu \\
& & & Revisi \\
$P>80$ & Sangat & Sangat & Tidak \\
& Valid & Praktis & Perlu \\
& & & Revisi \\
\hline
\end{tabular}

Untuk menguji efektivitas bahan ajar dilakukan dengan cara memberikan pretest-postest yang berisi soal kemampuan penguasaan konsep dan komunikasi matematis. Analisis hasil pretest-postest dilakukan dengan menggunakan statistik berupa uji normalitas, paired sample t-test, dan analisis $N$-gain.

\section{HASIL DAN PEMBAHASAN}

Dalam desain penelitian dan pengembangan ini menggunakan model pengembangan $4 \mathrm{D}$ yang terdiri dari empat tahap, yaitu: define, design, develope dan disseminate. Pada penelitian ini tahapan yang dilakukan terbatas pada tahap develop. Berikut uraian dari tiap tahapan yang dilakukan.

\section{A. Tahap Define}

Tahap ini merupakan tahap awal yang peneliti lakukan dalam penelitian dan pengembangan ini. Pada tahap ini dilakukan beberapa analisis diantaranya yaitu analisis awal-akhir, analisis mahasiswa, analisis materi ajar, analisis tugas dan analisis spesifikasi tujuan pembelajaran.

Analisis awal-akhir untuk mengetahui permasalahan yang dihadapi mahasiswa dalam pembelajaran Matematika Ekonomi di Jurusan Manajemen Fakultas Ekonomi dan Bisnis Universitas Bina Bangsa.

Berdasarkan hasil observasi peneliti melihat terdapat permasalahan yang terjadi pada perkuliahan Matematika Ekonomi yaitu perkuliahan kerap dilakukan dengan cara yang monoton dan konvensional. Bahan ajar yang disajikan dalam perkuliahan biasanya hanya berupa buku teks atau modul sehingga kadang membuat mahasiswa jenuh, kurang termotivasi untuk belajar. Ditambah adanya pandemi Covid-19 yang merubah sistem perkuliahan dari yang awal tatap muka menjadi pembelajaran jarak jauh melalui media online sehingga interaksi antara dosen dan mahasiswa dibatasi.

Perubahan pola pembelajaran ini memberikan kesempatan bagi para mahasiswa untuk dapat mengakses bahan ajar secara online. Analisis mahasiswa dilakukan untuk mengetahui karakteristik dari mahasiswa. Mahasiswa sebagai generasi millennial sangat akrab dengan teknologi. Karakteristik 
generasi milenial ini secara umum ditandai dengan meningkatnya penggunaan media komunikasi dan telekomunikasi digital. Analisis materi ajar berguna untuk menentukan materi yang akan dipelajari dalam pembelajaran.

Pada analisis ini dilakukan identifikasi materi-materi pokok yang akan dipelajari dan menyusunnya secara garis besar. Materi ajar ditentukan berdasarkan silabus pada Mata Kuliah Matematika Ekonomi. Analisis tugas mengacu pada kompetensi dasar yang ingin dicapai setelah proses pembelajaran. Pada analisis ini diidentifikasi tugas-tugas apa saja yang akan diberikan kepada mahasiswa baik tugas individu ataupun kelompok. Analisis spesifikasi tujuan pembelajaran menjabarkan indikator yang lebih spesifik berdasarkan analisis materi dan tugas yang telah dilakukan.

Berdasarkan analisis-analisis yang telah dilakukan maka peneliti kemudian merumuskan untuk mendesain bahan ajar Matematika Ekonomi berbasis Vlog (VideoBlogging) dengan topik bahasan materi "Matriks dan Penerapannya dalam Ekonomi dan Bisnis.

\section{B. Tahap Design}

Langkah selanjutnya peneliti mulai merencanakan untuk membuat desain awal bahan ajar matematika Ekonomi berbasis Vlog. Dari hasil analisis materi dan tujuan pembelajaran maka untuk desain awal bahan ajar Matematika Ekonomi berbasis Vlog yang dihasilkan dalam penelitian ini membahas satu topik/bab yang berjudul "Matriks dan Penerapannya dalam Ekonomi dan Bisnis". Dalam topik ini terbagi menjadi 4 subtopik utama yaitu
Konsep Dasar Matriks, Determinan dan Invers Matriks, Sistem Persamaan Linier dengan Matriks dan Aplikasinya dalam Ekonomi-Bisnis serta Analisis Input-Output. Untuk memproduksi bahan ajar berbasis Vlog, dibagi menjadi 3 tahapan diantaranya yaitu:

1) Praproduksi, pada tahapan ini peneliti mulai mengumpulkan asetaset yang diperlukan dalam memproduksi sebuat video (aset suara dan gambar), menyusun script atau naskah dan menentukan jadwal pengambilan gambar (syuting)

2) Produksi, pada tahapan ini peneliti mulai melakukan pengambilan gambar (shooting). Hal yang perlu diperhatikan dalan tahapan ini adalah pencahayaan, suara dan angle camera. Pencahayaan yang baik akan menghasilkan kualitas gambar yang baik. Agar suara terdengar jernih peneliti menggunakan microphone untuk meredam noise atau suarasuara bising dari eksternal. Meskipun perekaman dilakukan di dalam ruangan namun penggunaan microphone sangat membantu menghasilkan suara yang terdengar lebih jernih. Pada waktu pengambilan gambar angle camera pun harus diperhatikan supaya gambar yang dihasilkan proporsional dan enak dilihat.

3) Pascaproduksi, setelah pengambilan gambar (syuting) tahapan selanjutnya yaitu melakukan editing. Proses editing vlog yang penulis lakukan menggunakan aplikasi edit video yaitu Wondershare Filmora 9. Adapun tampilan desain awal bahan ajar Matematika Ekonomi berbasis Vlog disajikan pada Gambar 1 dan konsep dasar matriks pada Gambar 2. 


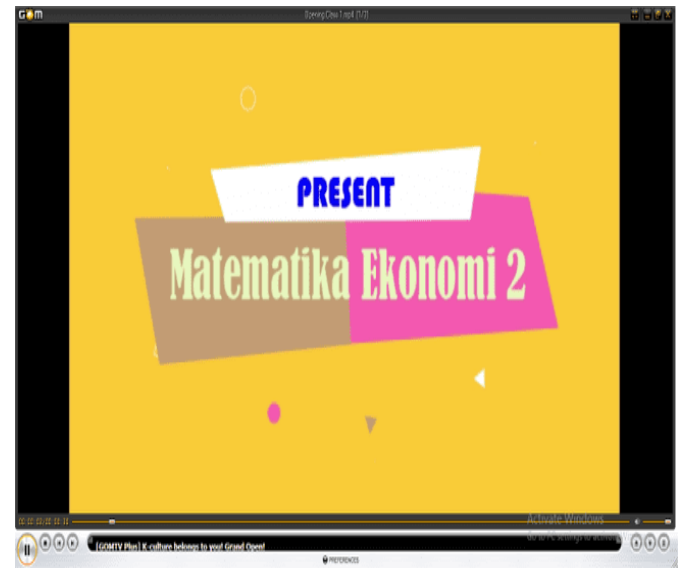

Gambar 1. Tampilan muka bahan ajar

Bagian awal dari desain bahan ajar yang dihasilkan memuat tampilan muka bahan ajar kemudian pengenalan identitas dosen penyaji. Dalam setiap scene pada bagian ini diiringi oleh latar musik yang atraktif sehingga menarik minat dan membuat semangat bagi pengguna bahan ajar ini yaitu mahasiswa. Di setiap awal sub-bab selalu diawali dengan pemaparan materi pokok apa saja yang akan dibahas dan tujuan yang diharapkan dapat dicapai oleh mahasiswa setelah mempelajari materi tersebut. Pada bagian akhir diberikan contoh soal dan latihan yang dapat membantu mahasiswa dalam penguasaan konsep matematis mereka.

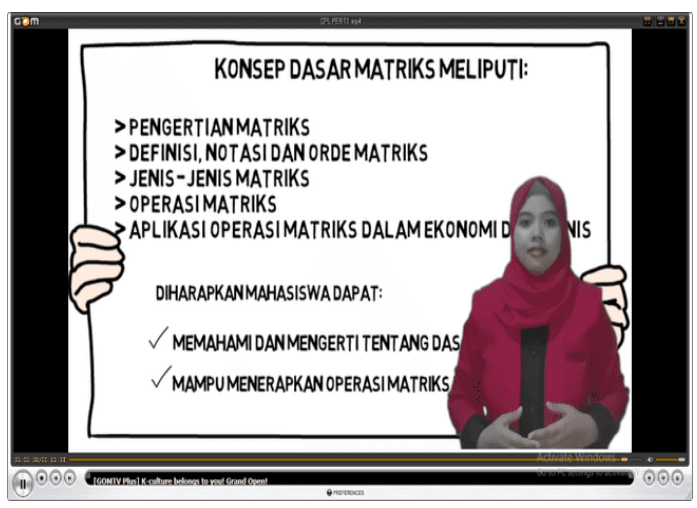

Gambar 2. Pemaparan materi dan capaian
Selain itu, dalam bahan ajar ini terdapat tugas yang harus dikerjakan baik secara individu ataupun kelompok yang harus disajikan dalam format video kemudian dishare dan direview bersama. Dengan metode ini tentunya akan merangsang kemampuan komunikasi matematis mahasiswa karena mereka dituntut untuk dapat menyampaikan apa yang mereka pahami secara lisan maupun tulisan yang terekam langsung di dalam video tersebut.

\section{Tahap Develop}

Setelah rancangan awal bahan ajar ini diproduksi tahap selanjutnya yaitu dilakukan validasi oleh para ahli yang terdiri dari ahli media, ahli materi dan ahli bahasa untuk menilai kevalidan dari bahan ajar sebelum diujicobakan pada subjek sasaran secara terbatas. Validasi ahli media dilakukan oleh 3 orang dosen dari jurusan Matematika, validasi ahli media dilakukan oleh 3 orang dosen dari jurusan Pendidikan Matematika dan validasi ahli bahasa dilakukan oleh 3 orang dosen pengampu mata kuliah Bahasa Indonesia, sehingga total keseluruhan validator berjumlah 9 orang. Rekapitulasi hasil penilaian dari ahli materi, ahli media dan ahli bahasa secara keseluruhan disajikan dalam tabel 3 berikut.

Tabel 3. Rekapitulasi Hasil Penilaian Para Ahli.

\begin{tabular}{ccccc}
\hline No & Validator & Skor & Persentase & $\begin{array}{c}\text { Kriteria } \\
\text { Kelayakan }\end{array}$ \\
\hline 1 & Ahli Materi & 44,67 & $81 \%$ & $\begin{array}{c}\text { Sangat } \\
\text { Valid }\end{array}$ \\
2 & Ahli Media & 51,67 & $86 \%$ & $\begin{array}{c}\text { Sangat } \\
\text { Valid }\end{array}$ \\
& & & & Sangat \\
3 & Ahli & 48,33 & $88 \%$ & Valid \\
\hline
\end{tabular}


Berdasarkan Tabel 3 hasil penilaian dari keseluruhan para ahli baik itu ahli materi, media dan bahasa menunjukan hasil kelayakan sangat valid sehingga desain bahan ajar Matematika Ekonomi berbasis vlog yang dikembangkan oleh peneliti layak digunakan/diujicoba tanpa revisi. Namun demikian, beberapa komentar juga diberikan oleh pada ahli guna meningkatkan kualitas dari bahan ajar.

Komentar dari para ahli materi diantaranya menyatakan bahwa pada bahan ajar berbasis v-log ini peneliti sudah sangat baik dalam menjelaskan materi, untuk selanjutnya agar lebih santai sehingga tidak kelihatan kaku ketika tampil dilayar. Komentar lainnya yaitu menyatakan bahwa penyampaian materi pembelajarannya sangat baik, mudah difahami dan dimengerti. Saran dari validator materi agar menambahkan beberapa contoh soal yang aplikatif lagi sebagai khazanah berpikir mahasiswa dan lebih baik lagi dijelaskan keterkaitan antara materi sebelumnya dengan materi selanjutnya.

Komentar yang diberikan oleh ahli media yaitu unsur kemampuan komunikasi matematis yang ingin dikembangkan harus lebih dimunculkan. Sedangkan saran yang diberikan oleh ahli media menyatakan bahwa bagaimana jika pada materi ditiap pertemuan dibuatkan ilustrasi dalam bentuk penyajian gambar atau contoh aplikatif dalam bentuk penyelesaian masalah pada kehidupan sehari-hari.

Sedangkan komentar yang diberikan oleh ahli bahasa diantaranya yaitu bahasa yang digunakan sudah sangat baik, sesuai dan mudah dipahami. Komentar lainnya menyatakan bahwa penggunaan diksi maupun simbol sudah baik. Adapun saran yang diberikan yaitu kalimat- kalimat motivasi ditambah lebih banyak agar mahasiswa berpikir bahwa Matematika Ekonomi itu mudah dan saran selanjutnya agar lebih ekspresif lagi dalam menyampaikan materinya. Komentar-komentar tersebut kami jadikan acuan dalam memperbaiki kualitas bahan ajar yang akan dipergunakan.

Setelah diperoleh hasil validitas dari para ahli, bahan ajar diujicobakan kepada sasaran subjek penelitian. Bahan ajar berbasis vlog yang telah peneliti produksi kemudian diupload ke channel Youtube (Gambar 3) agar dapat lebih mudah diakses secara daring. Peneliti cukup memberikan share link channel Youtube yang berisi bahan ajar berbasis vlog kepada mahasiswa sebagai subjek penelitian ini.

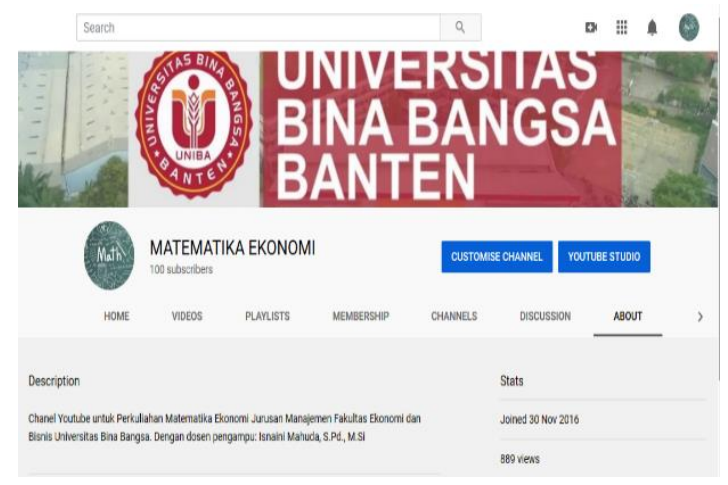

Gambar 3. Tampilan channel Youtube

Uji coba selanjutnya adalah uji coba kepada subjek penelitian yang dilakukan untuk mengukur kepraktisan dari bahan ajar yang dikembangkan. Uji coba kepraktisan dilihat berdasarkan tiga aspek yaitu dari sisi tampilan bahan ajar, penyampaian materi ajar dan manfaat yang diperoleh mahasiswa dari pembelajaran. hasil dari uji coba kepraktisan produk ditunjukkan oleh persentase rata-rata hasil penilaian yang diberikan oleh mahasiswa dapat dilihat pada Tabel 4. 
DOI: https://doi.org/10.24127/ajpm.v9i3.2995

Tabel 4. Rekapitulasi Hasil Penilaian Kepraktisan oleh Mahasiswa Per Indikator.

\begin{tabular}{cccc}
\hline No & $\begin{array}{c}\text { Indikator } \\
\text { Penilaian }\end{array}$ & Persentase & Kriteria \\
\hline 1 & Tampilan & $86 \%$ & Sangat \\
& Bahan Ajar & & Praktis \\
2 & Penyajian & $85 \%$ & Sangat \\
& Materi Ajar & & Praktis \\
3 & Manfaat dari & $79 \%$ & Praktis \\
& Pembelajaran & & \\
& Rata-rata & $83 \%$ & Sangat \\
& & & Praktis \\
\hline
\end{tabular}

\begin{abstract}
Berdasarkan tabel 4 diperoleh rata-rata persentase penilaian kepraktisan bahan ajar oleh mahasiswa yaitu sebesar $83 \%$ sehingga tingkat kepraktisan bahan ajar termasuk kedalam kriteria sangat praktis.

Ujicoba selanjutnya yaitu untuk mengukur keefektifan bahan ajar yang digunakan dengan melihat hasil pretestpostest. Pretest-postest dalam penelitian ini mengunakan instrument tes tertulis dalam bentuk Essay. Tes disusun berdasarkan indikator kemampuan penguasaan konsep dan komunikasi matematis. Hasil tes ini diukur dengan menggunakan normalitas gain ( $\mathrm{N}$-gain) kemudian dianalisis dengan uji paired sample t-test berbantu software IBM SPSS versi 25. Rekapitulasi hasil pengukuran $\mathrm{N}$-gain disajikan dalam Tabel 5.
\end{abstract}

Tabel 5. Rekapitulasi Hasil Pengukuran N-Gain

\begin{tabular}{cccc}
\hline Batasan & Kriteria & Jumlah & Persentase \\
\hline $\mathrm{g}>0,7$ & Tinggi & 1 & $4 \%$ \\
$0,3 \leq \mathrm{g} \leq 0,7$ & Sedang & 24 & $96 \%$ \\
$\mathrm{~g}<0,3$ & Rendah & 0 & $0 \%$ \\
\hline
\end{tabular}

Hasil dari pengukuran N-Gain dari 25 responden sebagai besar masuk dalam kriteria sedang. Adapun nilai rata-rata $\mathrm{N}$-gain ditunjukkan dalam Tabel 6.

Tabel 6. Hasil Analisis N-gain

\begin{tabular}{|c|c|c|c|}
\hline \multicolumn{2}{|c|}{ Rata-rata } & \multirow{2}{*}{$\begin{array}{l}N- \\
\text { gain }\end{array}$} & \multirow{2}{*}{ Kriteria } \\
\hline Pretes & Postes & & \\
\hline 51,4 & 80,2 & 0,59 & Sedang \\
\hline
\end{tabular}

Selanjutnya, dilakukan analisis dengan uji paired sample t-test berbantu software IBM SPSS versi 25. Uji paired sample t-test digunakan untuk mengetahui apakah ada perbedaan sebelum dan setelah penggunaan bahan ajar berbasis vlog dalam hal kemampuan penguasaan konsep dan komunikasi matematis mahasiswa. Untuk melakukan uji paired sample ttest data yang digunakan harus berdistribusi normal. Untuk itu dilakukan pengujian normalitas dengan menggunakan uji Shapiro Wilk. Tabel 7 adalah hasil pengujian normalitas dengan uji Shapiro-Wilk.

Tabel 7. Hasil Uji Normalitas.

\begin{tabular}{lrrr}
\hline & \multicolumn{3}{c}{ Shapiro-Wilk } \\
\cline { 2 - 4 } & Statistic & \multicolumn{1}{c}{ Df } & \multicolumn{1}{c}{ Sig. } \\
\cline { 2 - 4 } Pretes & .921 & 25 & .055 \\
Postes & .947 & 25 & .214 \\
\hline
\end{tabular}

Dari hasil uji normalitas dengan menggunakan Shapiro-Wilk diperoleh nilai sig baik pada pretest maupun postest lebih besar dari 0.05 maka dapat disimpulkan bahwa data berdistribusi normal. Berikutnya dilakukan analisis uji paired sample t-test yang hasilnya ditunjukan pada Tabel 8. 
DOI: https://doi.org/10.24127/ajpm.v9i3.2995

Tabel 8. Hasil Uji Paired Sample T-Test

\begin{tabular}{|c|c|c|c|c|}
\hline \multirow[b]{2}{*}{ Pair 1} & \multirow[b]{2}{*}{$\begin{array}{l}\text { Pretes } \\
\text { Postes }\end{array}$} & $\mathbf{T}$ & df & (2-tailed) \\
\hline & & -14.993 & 24 & .000 \\
\hline
\end{tabular}

Hipotesis yang digunakan dalam uji paired sampel t-test yaitu: $\mathrm{H}_{0}$ : Tidak ada perbedaaan antara hasil pretest dan posttest.

$\mathrm{H}_{1}$ : Ada perbedaaan antara hasil pretest dan posttest.

Kriteria pengujian:

1) Terima $\mathrm{H}_{0}$, jika Sig. $>0.05$

2) Tolak $\mathrm{H}_{0}$, jika Sig. $<0.05$

Berdasarkan tabel 8, diketahui nilai Sig. (2-tailed) dengan $\alpha=0.05$ adalah 0.000 maka Sig. $<0.05$, sehingga dapat disimpulkan bahwa ada perbedaan rata-rata antara hasil pretest dan postest. Hal ini mengindikasikan bahwa adanya pengaruh yang signifikan penggunaan bahan ajar Matematika Ekonomi berbasis vlog terhadap kemampuan penguasaan konsep dan komunikasi matematis pada materi Matriks dan Aplikasinya dalam Ekonomi dan Bisnis. Hasil analisis tes yang diukur dengan normalitas gain $(\mathrm{N}-$ gain) maupun paired sample t-test menyimpulkan bahwa bahan ajar Matematika Ekonomi berbasis vlog efektif untuk digunakan pada pembelajaran Matematika Ekonomi berbasis vlog berorientasi pada kemampuan penguasaan konsep dan kemampuan matematis.

Berdasarkan hasil penelitian menunjukkan bahwa vlog dapat dimanfaatkan sebagai media belajar dan dan memberikan dampak signifikan dalam meningkatkan kualitas proses belajar mengajar. Hal ini sejalan dengan penelitian yang dilakukan oleh Al Hibra (2019) dan Susanti (2020) yang telah berhasil mengembangkan media pembelajaran berbasis vlog. Selain itu, penggunaan bahan ajar berbasis vlog dapat meningkatkan kemampuan penguasaan konsep yang sejalan dengan hasil penelitian Fitriani (2017) dan Wachid Muzhaffar (2020). Dengan bahan ajar berbasis vlog mahasiswa dapat kapan saja dan dimana saja mengaksesnya serta vlog dapat diputar berulang-ulang sehingga mahasiswa dapat lebih mudah dalam memahami dan menguasai konsep yangd diajarkan. Begitupun dengan hasil penelitian yang menunjukan bahwa penggunaan bahan ajar berbasis vlog dapat meningkatkan kemampuan komunikasi matematis. Hasil ini sejalan dengan penelitian yang dilakukan oleh Mugara (2019) menyatakan bahwa pembelajaran dengan menerapkan bahan ajar berbasis vlog dapat meningkatkan keterampilan komunikasi mahasiswa.

Penggunaan bahan ajar

Matematika Ekonomi berbasis vlog memiliki beberapa kelebihan dan kekurangan. Kelebihan penggunaan bahan ajar Matematika Ekonomi berbasis vlog ini sangat cocok untuk digunakan oleh mahasiswa yang merupakan kaum milenial yang dikenal pro-gadget dan sangat tertarik dengan hal-hal yang berkaitan dengan perkembangan teknologi. Bahan ajar berbasis vlog yang memadukan unsur video, audio, gambar dan tulisan membuat belajar matematika membuat siswa rileks dan tidak monoton.

Selain itu, bahan ajar berbasis vlog ini sangat tepat digunakan saat pembelajaran online ditengah Pandemi Covid-19 sehingga mahasiswa dapat mengakses bahan ajar cukup melalui channel Youtube. Penggunaan bahan ajar Matematika Ekonomi berbasis vlog membuat mahasiswa lebih mudah dalam memahami konsep matematika karena dalam proses belajar mahasiswa 
dapat memutar ulang penjelasan dalam video sesuka mereka. Adapun kekurangan dari bahan ajar Matematika Ekonomi berbasis vlog ini yaitu bagi mahasiswa yang tinggal di pedalaman atau daerah yang sulit sinyal atau minimnya akses internet akan kesulitan menggunakan bahan ajar.

Pelaksanaan dalam penelitian terdapat kendala yang peneliti hadapi, diantaranya yaitu pada saat proses perekaman video peneliti belum terbiasa berbicara di depan layar kamera sehingga masih terlihat agak sedikit gugup dan kaku dalam membawakan materi. Selain itu proses editing video yang memakan waktu cukup lama dan membutuhkan kemahiran dalam pengguaan beberapa software serta membutuhkan komputer dengan spesifikasi yang mumpuni untuk proses editing video. Selain kendala yang dihadapi, penelitian ini juga memiliki keterbatasan waktu sehingga materi yang dibahas hanya memuat satu topik/bab yang berjudul "Matriks dan Aplikasinya dalam Ekonomi dan Bisnis" dengan 4 (empat) sub-topik utama yaitu Konsep Dasar Matriks, Determinan dan Invers Matriks, Sistem Persamaan Linier dengan Matriks dan Aplikasinya dalam Ekonomi-Bisnis serta Analisis Input-Output

\section{KESIMPULAN DAN SARAN}

Berdasarkan hasil penelitian dan pembahasan dapat dikemukan 4 (empat) kesimpulan. Pertama, Pertama, bahan ajar Matematika Ekonomi berbasis vlog yang dikembangkan dalam penelitian ini memuat bagian utama yang terdiri dari halaman muka dan identitas dosen penyaji, bagin inti yaitu pemaparan tujuan pembelajaran dan penjelasan materi secara rinci serta bagian akhir berisi contoh soal, latihan beserta tugas yang harus dikumpulkan dalam bentuk vlog. Pada tiap bagian dalam bahan ajar ini diiringi oleh latar musik yang atraktif sehingga menarik minat dan membuat semangat bagi pengguna bahan ajar. Kedua, dari hasil uji kevalidan dari para ahli yang terdiri dari ahli materi, ahli media dan ahli bahasa diperoleh bahwa bahan ajar Matematika Ekonomi berbasis vlog termasuk pada kriteria kelayakan sangat valid. Ketiga, hasil uji kepraktisan oleh mahasiswa pengguna bahan ajar diperoleh bahwa bahan ajar Matematika Ekonomi berbasis vlog termasuk dalam kriteria sangat praktis. Keempat, hasil uji efektivas bahan ajar diperoleh bahwa bahan ajar Matematika Ekonomi berbasis vlog efektif dalam meningkatkan kemampuan penguasaan konsep dan komunikasi matematis mahasiswa. Saran pemanfaatan pengembangan bahan ajar berbasis vlog ini dapat menjadi referensi bagi para pendidik atau dosen terlebih dalam masa pandemi Covid-19 dimana pembelajaran dilakukan secara jarak jauh sehingga dengan bahan ajar berbasis vlog ini mahasiswa dapat dengan mudah mengakses bahan ajar secara daring melalui channel Youtube. Selain itu, untuk penelitian selanjutnya dapat mengembangkan desain bahan ajar berbasis vlog ini untuk materi matematika yang lainnya. Penelitian ini dilakukan terbatas pada tahap develop sehingga untuk penelitian selanjutnya diharapkan dapat tercapai hingga tahap desiminate.

\section{DAFTAR PUSTAKA}

Akuba, S. F. (2020). Pengaruh Kemampuan Penalaran , Efikasi Diri dan Kemampuan Memecahkan Masalah Terhadap Penguasaan Konsep Matematika. JNPM (Jurnal Nasional Pendidikan Matematika), 4(1) , 44-60. 
Al Hibra, B. H. (2019). Development of Vlog Learning Media (Video Tutorial) on Student Materials. Tax at SMK PGRI 1 Jombang. Internasional Journal of Education Research Review, 4(3) , 435-438.

Arfah. (2018). Hubungan Kemampuan Komunikasi Matematis dan Kemampuan Pemahaman Konsep Matematika Siswa Kelas $\mathrm{X}$ SMAN 1 Bajeng. Jurnal Nalar Pendidikan. Vol 6 (2), 8694.

Arikunto. (2012). Dasar-dasar Evaluasi Pendidikan. Jakarta: Bumi Aksara.

Creswell, J. (2013). Research Design: Pendekatan Kualitatif, Kuantitatif dan Mixed. Terjemahan Fawaid, A. Yogyakarta: Pustaka Pelajar.

David, E. R. (2017). Pengaruh Konten Vlog dalam Youtube terhadap Pembentukan Sikap Mahasiswa Ilmu Komunikasi Fakultas Ilmu Sosial dan Politik Universitas Sam Ratulangi. Jurnal Acta Diurna, 6(1).

Fitriyani, L. D. (2017). Pengembangan Media Pembelajaran Vlog (Video Blogging) Padamateri Usaha Dan Energiuntuk Menumbuhkan Kemandirian dan Meningkatkan Penguasaan Konsepfisikasiswa Kelas X Sma Negeri 2 Ngaglik. E-journal Pendidikan Fisika Jurusan Pendidikan Fisika FMIPA UNY Vol 7 (6) .
Hodiyanto. (2017). Kemampuan Komunikasi Matematis dalam Pembelajaran Matematika. AdMathEdu Vol.7 (1) , 9-18.

Irawan, A. (2014). Pengaruh Kecerdasaan Numerik dan Kemampuan Konsep Matematika Terhadap Kemampuan Berpikir Kritik Matematika. Jurnal Formatif 4(1) , 46-55.

Karamina, S. (2020). The Role of Social Studies Teacher in the Use of YouTube Vlog-Based Learning Media. Proceedings of the International Conference on Science and Education and Technology (ISET 2019 (pp. 10). (pp. 186-190). Atlantis Press.

Lestari, N. (2019). Improving the Speaking Skill by Vlog ( video blog ) as Learning Media: The EFL Students Perspective Improving the Speaking Skill by Vlog ( video blog ) as Learning Media: The EFL Students Perspective. International Journal of Academic Research in Business and Social Sciences, 9(1), 915925.

Mugara, R. E. (2019). Penyusunan Bahan Ajar Berbasis Vlog Dalam Meningkatkan Keterampilan Komunikasi Mahasiswa PGSD IKIP Siliwang. Jurnal Ilmiah UPT P2M STKIP Siliwangi, Vol. 6 (1), 63-72.

Priana, R. Y. (2017). Pemanfaatan Vlog Sebagai Media Pembelajaran Teritegrasi Teknologi Informasi. Prosiding Seminar Nasional Pendidikan FKIP UNTIRTA Vol 1(2), (pp. 313-316). 
DOI: https://doi.org/10.24127/ajpm.v9i3.2995

Putri, Y. U. (2020). Efektivitas Perangkat Pembelajaran Matematika Berbasis Pendekatan Contextual Teaching and Learning terhadap Kemampuan Komunikasi Matematis. AKSIOMA: Jurnal Program Studi Pendidikan Matematika, 9(1) , 205-212.

Susanti, E. D. (2020). Pengembangan Media ECHA (Elaboration, Cover Song, Historycal Content, Audio Visual) Berbasis Vlog Dalam Pembelajaran Sejarah. Jurnal Pendidikan: Teori, Penelitian dan Pengembangan Vol5 (3) , 326-331.

Wachid Muzhaffar, I. R. (2020). Pengembangan Media Pembelajaran Vlog pada Mata Pelajaran Dasar Desain Grafis di SMK N 1 Surabaya. Jurnal Information Technology and Education, 04 , 104-109. 